\title{
Pendampingan optimalisasi pengelolaan Badan Usaha Milik Desa Penyengat Olak Kecamatan Jambi Luar Kota Kabupaten Muaro Jambi
}

\author{
Citra Darminto* dan Haryadi \\ Universitas Jambi \\ * darmintocitra2014@gmail.com
}

\begin{abstract}
Abstrak. Pendampingan dalam pengelolaan Badan Usaha Milik Desa ini bertujuan untuk memberi masukan atas kendala-kendala yang dihadapi oleh pemerintah desa untuk mencapaian pengelolaan Badan Usaha Milik Desa (BUMDes) yang belum optimal. Sesuai dengan undang-undang No. 6 Tahun 2014, bahwasannya desa diberikan kewenangan dalam melakukan penyelenggaraan pemerintahan sesuai dengan kepentingan masyarakat desa.

Kewenangan desa telah diberikan berdasarkan hak usul desa yang mencakup urusan pemerintahan yang diberikan oleh kabupaten /kota yang telah diserahkan kepada desa. Desa memiliki kewajiban dalam memberikan penyelenggaraan pemerintahan yang bertujuan untuk mensejahterakan masyarakatnya. Demi tercapainya hal tersebut ditunjang pula dengan Pendapatan Asli Desa (PADes) untuk memperkuat perekonomian desa, melalui penguatan BUMDes yang berpihak sebagai institusi dalam mengoptimalisasi Pendapatan Asli Desa. Ketidakcapaian Pendapatan Asli Desa (PADes), terjadi dikarenakan masih kurangnya peran BUMDes. Berdampak pula di masyarakat dalam penguatan perekonomian masyarakat. Hal inilah yang yang terjadi di Desa Penyengat Olak kecamatan jambi luar kota kabupaten muaro jambi, yang menyebabkan belum bisa mandiri di berbagai aspek. Oleh karena itu dengan adanya sosialisasi dalam pengabdian kepada masyarakat ini diharapkan dapat memberikan dampak yang lebih baik dan solusi dalam penyelesaian permasalahan yang terjadi serta bertujuan menggali potensi desa dalam rangka pemberdayaan masyarakat yang berkelanjutan.
\end{abstract}

Kata kunci: BUMDes, PADes, pemberdayaan

\begin{abstract}
The assistance in the management of Village-Owned Enterprises aims to provide input on constraints faced by the village government to achieve the management of Village-Owned Enterprises (BUMDes) that have not been optimal. In accordance with law No. 6 of 2014, that villages are given the authority to carry out the administration of government in accordance with the interests of the village community. Village authority has been granted based on village propositions which cover government affairs provided by the district / city that have been submitted to the village. Villages have an obligation to provide governance that aims to prosper their society. In order to achieve this, the Village Original Income (PADes) was also supported to strengthen the village economy, through strengthening BUMDes that sided with the institution in optimizing Village Original Income. Inaccessibility of Village Original Income (PADes) occurs due to the lack of role of BUMDes. It also has an impact on society in strengthening the economy of the community. This is what happened in Penyengat Olak Village, jambi sub-district outside the city of Muaro Jambi district, which caused it to be unable to be independent in various aspects. Therefore, the existence of socialization in community service is expected to provide a better impact and solutions in solving the problems that occur and aim to explore the potential of the village in the context of sustainable community empowerment.
\end{abstract}

Keywords: BUMDes, PADes, Empowerment

To cite this article: Darminto, C., \& Haryadi. 2019. Pendampingan optimalisasi pengelolaan Badan Usaha Milik Desa Penyengat Olak Kecamatan Jambi Luar Kota Kabupaten Muaro Jambi. Unri Conference Series: Community Engagement 1: 46-50. https://doi.org/10.31258/unricsce.1.46-50

(c) 2019 Authors

Peer-review under responsibility of the organizing committee of Seminar Nasional Pemberdayaan Masyarakat 2019 


\section{PENDAHULUAN}

Demi tercapainya kemajuan dan kemandirian daerah perlu diadakannya pengembangan yang ada di daerah, oleh sebab itu maka strategi pemerintahan yang ada perlu dimaksimalkan sedemikian rupa, sehingga capaiannya dapat maksimal guna mendukung peningkatan yang lebih baik dalam berbagai aspek kehidupan. Munculnya otonomi daerah membuat penyelenggaraan daerah dapat memaksimalkan potensi yang ada didaerah. Otonomi berlangsung menjadikan daerah dapat memenuhi kebutuhan daerahnya sendiri, hal ini terjadi daerah dapat mengetahui kebutuhannya masing-masing. Sepanjang perjalanan dari waktu kewaktu pemerintah mulai mengeluarkan Undang-Undang No.6 Tahun 2014 tentang desa. Dimana desa sebagai daerah otonom baru diberi kuasa penuh untuk melakukan penyelengaraan pemerintahan seluas-luasya. Desa diberi kewenangan dalam mengatur dan mengelola desanya sendiri sesuai dengan kebutuhan dan kepentingan masyarakat desa.

Dengan terbitnya Undang-Undang No. 6 Tahun 2014 tentang Desa, terjadi pergeseran peran desa yang semula berperan sebagai local state government, maka saat ini desa sebagai pemerintahan masyarakat, hybrid antara self governing community dan local self government. Desa memerlukan sistem pengelolaan baru, sehingga desa mampu mewujudkan perannya sesuai dengan amanat otonomi desa. Adanya otonomi desa, desa memiliki kewenangan dalam melakukan perencanaan, kebutuhan akan pelayanan publik, serta mencakup aspek yang menjadi kepentingan masyarakat desa, maka diperlukan adanya sebuah lembaga dalam membangun penyelenggaran pemerintahan dengan mengembangkan usaha-usaha yang dikira menjadi potensi dari desa untuk kepentingan dan kesejahteraan masyarakat. Demi tercapainya pembangunan dan kesejahteraan masyarakat perlu adanya partisipasi dari masyarakat dalam mendorong berjalannya program dan kegiatan yang dilakukan oleh penyelenggara pemerintah desa. Partisipasi masyarakat sangatlah dominan dalam mewujudkan tercapainya harapan guna menumbuhkan percepatan perekonomian masyarakat. Terbitnya undang-undang otonomi desa diharapkan dapat menjadikan masyarakat desa menuju taraf yang lebih baik. Hal inilah yang nantinya akan munculnya tata kelola masyarakat desa yang lebih paritisipatif dan akuntabel dalam memenuhi perekonomian menuju kesejahteraan. Otonomi desa diharapkan menjadikan desa dapat mandiri di berbagai aspek demi tercapianya kebutuhan masyarakat sesuai dengan potensi yang ada di desa. Dengan pengoptimalan potensi desa dengan maksimal, desa dapat mengurangi beban dari pemerintah pusat, hal ini desa dapat mandiri dalam penyelenggaraan pemerintahannya. Kemandirian desa tentunya tak lepas dari pengelolaan desa oleh seperangkat pemerintahan desa yang berpihak kepada masyarakat dalam menjalankan amanah yang diberikan oleh masyarakat desa. Terwujudnya kemandirian desa demi tercapainya desa yang sejahtera, maka desa mencari dana sendiri dengan mengelola serta mengembangkan potensi didesa, sesuai dengan kebutuhan dan kepentingan masyarakat setempat. Undang-Undang No. 6 Tahun 2014 menyebutkan bahwa desa mendapat bantuan dari APBN pusat yang dikenal dengan ADD (Alokasi Dana Desa). Namun bukan serta merta desa hanya menerima dan mengandalkan hibah dari APBN semata. Desa perlu mengembangkan keuangan desanya sendiri dengan mengembangkan potensi desa baik Sumber Daya Alam (SDA) maupun Sumber Daya Manusia (SDM) guna mencapai pendapatan asli desa yang maksimal. Pembangunan desa dicapai dengan dengan pengelolaan yang baik dari keuangan desa itu sendiri. Pada dasarnya bantuan pendapatan asli desa masih berorientasi dari pemerintah pusat maupun pemerintah kabupaten/kota. Sehingga apabila hanya mengandalkan sebatas bantuan yang di luncurkan oleh pemerintah maka pengelolaan dan pembangunan yang ada didesa tak akan maksimal. Hal inilah desa perlu mengembangkan dan adanya pengaturan pengelolaan pendapatan asli desa. Guna mencapai pendapatan asli desa yang maksimal desa dianjurkan untuk mendirikan BUMDes sesuai dengan kepentingan masyarakat desa. Landasan dalam mendirikan BUMDes yakni Undang-Undang No. 6 Tahun 2014 tentang Desa yang termuat dalam pasal 87 mengenai Badan Usaha Milik Desa (BUMDes). Badan Usaha Milik Desa (BUMDes) dibentuk berguna untuk mengelola dan mengatur perekonomian di desa sesuai dengan kepentingan masyarakat yang ada di desa. Dengan adanya BUMDes maka pemerintahan desa turut serta berkecimpung dalam penguatan perekonomian masyarakat desa sebagai upaya dalam membantu pemerintaha pusat. Desa bukan hanya sekedar menerima bantuan dan selalu dimanjakan namun desa diharapkan dapat menjadi mandiri guna mewujudkan kesejahteranaan masyarakat. BUMDes sebagai badan usaha, seluruh atau sebagian besar modalnya dimiliki desa, karena itu pengembangan BUMDes merupakan bentuk penguatan terhadap lembaga-lembaga ekonomi desa serta merupakan alat pendayagunaan ekonomi lokal dengan ragam jenis potensi yang ada didesa, lebih dari itu BUMDes menjadi tulang punggung perekonomian pemerintahan desa guna mencapai peningkatan kesejahteraan warganya. Hal ini penguatan dan pengelolaan BUMDes sangat diperlukan, karena sebagai agen dalam menunjang perekonomian masyarakat. 
Pelaksanaan dalam pemberdayaan perlunya juga pendekatan dalam kelompok masyarakat, bukan hanya sekedar individualnya saja, namun juga menyeluruh di lapisan masyrakat yang ada didesa.

Pada tahun 2017 keberadaan pendapatan asli desa Penyengat Olak masih belum memenuhi target yang maksimal hal ini dikarenakan BUMDes yang di bentuk belum mengalami perubahan yang signifikan sehingga berdampak pula pada pendapatan asli desa. Seiring berjalan waktu dengan mengevaluasi kinerja penyelenggaraan pemerintah desa, pada tahun 2018 dibentuklah BUMDes yang diharapkan dapat menjadi penyalur dan penguatan serta kesejahteraan masyarakat desa Penyengat Olak. Kegiatan yang dilakukan BUMDes desa Penyengat Olak yakni bergerak dibidang cathering, sewa menyewa gor, pemberdayaan bagi kaum wanita, serta pemberdayaan teknisi otomotif. Dalam menjalankan program-program yang dibina masih berjalan masif dan belum berjalan maksimal. Hal ini pengelolaan BUMDes yang belum terarah dan belum maksimal. Hal ini lah yang menghambat terjadinya penguatan ekonomi dalam masyarakat desa Penyengat Olak. Sosialisasi ini penting dilakukan, untuk memberikan solusi dan penyelesaian yang jelas dalam mengelola BUMDes. Hal ini berdampak pada kepentingan dan kesejahteraan masyarakat desa Penyengat Olak

\section{METODE PENERAPAN}

Dalam Optimalisasi Pengelolaan Badan Usaha Milik Desa (BUMDes) ini dilakukan sesuai dengan persoalan yang telah dikemukakan pada bagian permasalahan dan solusinya. Maka metode yang digunakan yaitu:

1. Mengidentifikasi pengelolaan BUMDes di Desa Penyengat Olak,

2. Memberikan penyuluhan dan sosialisasi tentang pentingnya BUMDes dan terhadap kesejahteraan masyarakat dan pembanggunan desa,

3. Melakukan Identifikasi sumber daya yang dimiliki oleh desa penyengat olak. Pada tahapannya akan diawali dengan pemberian sosialisasi tentang penting masyarakat masyarakat dalam mengoptimalkan BUMDes.

Pada tahapan ini Dosen, mahasiswa dan para stakeholder secara langsung terlibat dalam pelaksanaan program ini. Kegiatan ini pula diharapkan mampu mengubah pola pikir dan pola tindak masyarakat desa tentang partisipasi pengelolaan BUMdes, diharapkan kegiatan ini dapat mengatasi persoalan BUMDes, serta diharapkan juga kegiatan ini dapat memberdayakan elemen masyarakat di desa penyengat olak itu sendiri, bisa dari kaum muda dengan karang tarunanya, ataupun kaum perempuan desa penyengat olak, atau elemen lainnya di desa yang merasa sanggup dalam mengelolaan BUMDes yang akan dilakukan secara kontinyu. Tentu sebelumnya mahasiswa akan diberikan pembekalan oleh dosen pembimbing lapangan tentang urgensitas optimalisasi pengelolaan BUMDes dan juga target yang akan dicapai melalui program ini.

\section{HASIL DAN KETERCAPAIAN SASARAN}

Pelaksanaan kegiatan pengabdian diawali dengan riset pendahuluan untuk mengidentifikasi pokok permasalahan dan potensi desa yang dapat dikembangkan melalui kegiatan pengabdian. Pada proses riset ditemukan permasalahan utama yang dihadapi oleh Badan Usaha Masyarakat Desa (BUMDes) Penyengat Olak, persoalan tersebut pada dasarnya terletak pada merubah pola pikir masyarakat sangat sulit, apa lagi ditengarai adanya ego serta rasa acuh terhadap program-program yang ada dari desa. Isu golongan masih merebak belum mau untuk saling berkontribusi bersama. Sementara itu program yang dijalankan dari BUMDes Penyengat Olak juga terlalu banyak. Bahkan masyarakat hanya tau kalau didesa mereka ada BUMDes saja, namun dalam penyelenggaraannya masyarakat tidak tau apa-apa saja programnya. Bahkan itu tidak pernah ada sosialisasinya mengenai BUMDes, baik itu dari RT atau apa lagi dari pengelola BUMDesya sendiri. Berangkat dari fakta lemahnya tata kelola BUMDes dan minimnya penyebarluasan informasi maka kegiatan Pengabdian difokuskan untuk menyelesaikan kedua persoalan tersebut.

Sejalan dengan paradigma di atas, kegiatan pengabdian masyarakat ini juga menggunakan pendekatan buttom up yang sejalan dengan pembangunan yang sedang dilakukan oleh Indonesia yang dimulai dari pinggiran dengan memperkuat desa melalui pendanaan dana desa. Dengan demikian desa memiliki kesempatan yang besar untuk merencanakan pembangunan yang bertujuan kesejahteraan masyarakat melalui BUMDes berkelanjutan.

Selama bulan maret hingga Juni kegiatan pengabdian dilakukan dengan menekankan pada aspek pertama: penyediaan akses yang lebih terbuka, luas dan lebar terhadap sumber-sumber daya seperti modal, informasi, kesempatan berusaha dan memperoleh kemudahan/fasilitas. Selain itu juga Aktifitas Pengabdian masyarakat melakukan pendampingan berupa sosialisasi Optimalisasi pengelolaan BUMDes yaitu dengan pengorganisasian BUMDes, Kerjasama Dengan Pemerintah Kabupaten, Pengendalian dan Penyebarluaskan 
Informasi Potensi Desa Penyengat Olak. Kedua, pengembangan potensi SDM maupun kelembagaan masyarakat. Kegiatan yang dilakukan adalah dengan pelatihan, pendampingan dan demonstrasi, dan ketiga penyertaan masyarakat dalam proses perumusan perencanaan dan implementasi kebijakan. Cara ini menggunakan paradigma people-based and people-oriented development yang dilakukan melalui curah pendapat, berdiskusi, musyawarah dan menentukan kebijakan pengelolaan BUMDes.

Pasca pelaksanaan kegiatan pengabdian dilakukan evaluasi terhadap seluruh proses penyelenggaraan untuk memperoleh informasi mengenai tingkat capaian program yang telah direncanakan. Hasil evaluasi kegiatan menunjukkan bahwa adanya peningkatan pengetahuan tentang pengelolaan BUMDes yang mencakup aspek sosial, ekonomi dan lingkungan. Pengetahuan tersebut disertai dengan peningkatan motivasi kelompok sasaran kegiatan pemberdayaan, motivasi ini ditunjukkan melalui adanya keterlibatan aktif masyarakat seperti penyediaan Mni Market, UMKM Desa Penyengat Olak. Kemampuan manajerial dan kecakapan teknis dalam pengelolaan BUMDes juga mengalami peningkatan yang ditunjukkan dengan aktifitas promosi melalui saluran komunikasi baru. Promosi Potensi yang dimiliki Desa Penyengat Olak melalui media baru yang popular mulai intensif disertai dengan konten-konten yang informatif, akan tetapi penggunaan wadah baru ini perlu mendapat perhatian lebih karena konten-konten yang disajikan masih kurang menarik. Begitupula dengan ketersebaran informasi, informasi belum tersebar secara massif melalui jejaring saluran komunikasi dengan pengguna media yang sudah popular. Aktifitas pendampingan pengelolaan BUMDes berdampak pada peningkatan jumlah UMKM di Desa Penyengat Olak, keberadaan BUMDes dirasa memberi pengaruh terhadap usaha-usaha masyarakat yang menjadi bagian dari aktifitas UMKM masyarakat desa melakukan aktifitas baru seperti kerajinan tangan, makanan, Souvenir, serta pembanggunan Objek wisata yang masih tahap pembangunan. Dengan adanya aktifitas baru maka melahirkan sumber perekonomian baru atau alternatif bagi masyarakat setempat yang selama ini hanya bergantung pada sektor Perikanan dan pertanian dan akan berdampak langsung bagi pemasukan BUMDes yang mengelola potensi-potensi yang saat ini dimiliki oleh masyrakat Desa Penyengat Olak.

\section{KESIMPULAN}

Kegiatan pengabdian melalui transfer pengetahuan, pelatihan dan pendampingan berdampak pada meningkatnya pengetahuan dan kemampuan pengelolaan BUMDes yang dapat dikembangkan sebagai aset. Pengelolaan BUMDes mulai mengarah pada penggunaan konsep berkelanjutan yang memperhatikan aspek sosial ekonomi dan lingkungan. Dari aspek ekonomi berdampak pada terbentuknya potensi sumber pendapatan baru bagi masyarakat sekitar. Hal ini terlihat dengan adanya usaha baru seperti UMKM dan tenpat-tempat Wisata yang mulai dijadikan sebagai sumber perekonomian masyarakat dan berkontribusi bagi BUMDes. Dengan demikian, pengelolaan BUMDes sebagai sumber pendapatan baru bagi masyarakat merupakan salah satu cara mengatasi persoalan ekonomi masyarakat akibat situasi global. Pengelolaan BUMDes pada desa membutuhkan kemampuan kerjasama dan jejaring yang baik untuk menunjang keberlanjutan BUMDes Penyengat Olak. Oleh karena itu, kegiatan pendampingan masyarakat selain tranfer pengetahuan, pelatihan dan pendampingan, pendampingan lebih lanjut dalam membangun jejaring dan menjalin dengan berbagai stakeholder menjadi penting dilakukan.

\section{DAFTAR PUSTAKA}

Amir, M. T. 2011. Manajemen Strategik Konsep dan Aplikasi. Jakarta. PT Raja Grafindo Persada.

Andreas, \& E. Savitri. 2016. Peran Pemberdayaan Ekonomi Masyarakat Pesisir dan Modal Sosial Dalam Meningkatkan Kesejahteraan di Kabupaten Meranti dan Rokan Hilir.

Bagong, S., dkk. 2008. Metode Penelitian Sosial. Jakarta: Prenada Media Grup.

Ibnouf, M. H., M. N. Sheqwarah, \& K. I. Sultan. 2015. An Evaluation of the Participatory Learning and Action (PLA) Training Workshop. Journal of Agricultural Science 7(12): 144-150. https://doi.org/10.5539/jas.v7n12p144

Kompas.com. Badan Usaha Milik Desa Memperkuat Ekonomi Desa. https://ekonomi.kompas.com/read/2015/10/26/190837926/Badan.Usaha.Milik.Desa.Memperkuat.Ekonomi.Desa. Diakses pada Senin, 14 Januari 2019, pukul 10.30.

Nilawati, E. 2018. Analisis Manajemen Badan Usaha Milik Desa (BU.MDesa) "Hanyukupi” Desa Ponjong Kecamatan Ponjong Kabupaten Gunungkidul. Jurnal Wacana Kerja. 
Novia, K. Konsep, Prinsip, Model, dan Tujuan Manajemen Strategis Sektor Publik. Universitas Indo Global Mandiri, Palembang.

Permendesa Nomor 4 Tahun 2015 tentang Pendirian dan Pengelolaan, dan Pembubaran Badan Usaha Milik Desa. Berita Negara Republik Indonesia Tahun 2015 Nomor 296.

Rusdianto, S. 2013. Hukum Otonomi Daerah. Bandung. PT Refika Aditama.

Sulistiyani, A. T., \& Y. Wulandari. 2017. Proses Pemberdayaan Masyarakat Desa Sitimulyo, Kecamatan Piyungan , Kabupaten Bantul dalam Pembentukan Kelompok Pengelola Sampah Mandiri. Indonesia Journal If Community Engagement 2(2): 146-162.

Taufiqurohkhman. 2016. Manajemen Strategik. . Cetakan pertama 2016. Jakarta: Fakultas Ilmu Sosial dan Ilmu Politik, Universitas Prof. Dr. Moestopo Beragama.

Undang-undang Nomor 6 Tahun 2014, tentang Desa, pasal 87 BAB X.

Undang-undang Republik Indonesia Nomor 6 Tahun 2014 Tentang Desa. 2014. Indonesia. https://doi.org/10.1017/CBO9781107415324.004

Widayanti, S. 2012. Pemberdayaan Masyarakat: Pendekatan Teoritis. Welfare, Jurnal Ilmu Kesejahteraan Sosial 1(1): $87-102$.

Yanuar, A. 2012. Metode Penelitian Sosial Kualitatif. Bandung: PT Refika Aditama.

Zakaria, F., \& R. D. Suprihardjo. 2014. Konsep Pengembangan Kawasan Desa Wisata di Desa Bandungan Kecamatan Pakong Kabupaten Pamekasan. Jurnal Teknik Pomits 3(2): 245-249. 